

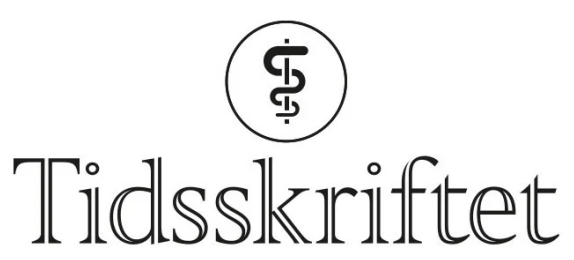

DEN NORSKE LEGEFORENING

\title{
T.B. Wyller svarer
}

\author{
KOMMENTAR
}

TORGEIR BRUUN WYLLER

t.b.wyller@medisin.uio.no

Torgeir Bruun Wyller er professor.

Forfatteren har ikke oppgitt noen interessekonflikter.

Jeg vil takke Jon Magnussen for hans innspill, som gir meg anledning til å presisere noen av mine synspunkter. Til min glede konstaterer jeg at han i hovedsak ser ut til å være enig $\mathrm{i}$ at en justering av dagens system er påkrevet. Som jeg har påpekt, er vårt alternative forslag (1 1 ) på ingen måte "fiks ferdig», og det er flott at det kan danne utgangspunkt for en diskusjon om veien videre.

Magnussen har helt rett i at ethvert finansieringssystem kan korrumperes og ha uønskede vridningseffekter. En ren rammefinansiering kan f.eks. bli et insentiv for sykehusene til å redusere nyttig aktivitet - akkurat som det nåværende systemet med innsatsstyrt finansiering er et insentiv til å øke målbar aktivitet, uansett om den er reell og uansett om den er nyttig eller ikke. Isolerte endringer av enkeltelementer i systemet for styring av sykehusene kan altså komme til å få skuffende liten effekt. Hovedsaken er derfor å vri helheten over mot et system der politikken setter rammene og sunne helsefaglige premisser i større grad styrer detaljene. Det er verd å merke seg at optimal innretning av et slikt system ikke er resultat av helseøkonomiske kalkyler, men av politiske valg.

Som Magnussen også helt korrekt påpeker, er det mye i dagens system som skiller seg fra tradisjonell kapitalisme, f.eks. det nitidige kontroll- og rapporteringsvesenet med tilhørende byråkrativekst, fravær av reell konkurranse, og ikke minst det faktum at sykehusene er skattefinansierte og offentlig drevet. Det er nettopp derfor det er så uhensiktsmessig å bruke et styringssystem som er så sterkt inspirert av kapitalistiske virksomheter. «Markedsimitasjon» er muligens et mer akademisk ord for det samme, men «kvasikapitalisme» er minst like dekkende og mer selvforklarende.

\section{LITTERATUR}

1. Haug L, Jensen B, Gisvold SE et al. Presentasjon av et alternativ til helseforetaksmodellen. Samfunn og økonomi. https://www.samfunnogokonomi.no/2021/o7/presentasjon-av-et-alternativ-tilhelseforetaksmodellen/ Lest 6.8.2021.

Publisert: 11. oktober 2021. Tidsskr Nor Legeforen. DOI: 10.4045/tidsskr.21.0662

(C) Tidsskrift for Den norske legeforening 2023. Lastet ned fra tidsskriftet.no 26. april 2023. 
